\title{
КЛІНІЧНА ОФТАЛЬМОЛОГІЯ
}

\author{
П. А. Бездітко ${ }^{1}$, М. А. Карлійчук ${ }^{2}$ \\ ${ }^{1}$ Харківський національний медичний університет МОЗ України \\ - м. Харків, Україна, \\ 2 Буковинський державний медичний університет МОЗ України \\ - м. Чернівці, Україна
}

\section{ОСОБЛИВОСТІ ТОВЩИНИ РЕШІТЧАСТОЇ ПЛАСТИНИ СКЛЕРИ У ХВОРИХ $І 3$ ДІАБЕТИЧНОЮ ОПТИЧНОЮ НЕЙРОПАТІЕЮ}

\begin{abstract}
У роботі описані зміни товщини решітчастої пластини склери у хворих на цукровий діабет у порівнянні з показниками здорових осіб, а також зміни товщини решітчастої пластини склери у хворих із різними стадіями діабетичної оптичної нейропатії. Крім того, наведено зміни площі склерального каналу решітчастої пластини залежно від іiі товщини у хворих на цукровий діабет.

Ключові слова: діабетична оптична нейропатія, решітчаста пластина склери, иукровий діабет, склеральний канал.
\end{abstract}

На даний час у патогенезі діабетичної оптичної нейропатії (ДОН) доведено значення метаболічного, судинного та аутоімунного механізмів $[1,15]$. Нещодавно було виявлено зміну біомеханічних властивостей решітчастої пластини при цукровому діабеті (ЦД) ex vivo, а саме: посилення іiі жорсткості та зменшення еластичності [13], пов'язане з крослінкінгом колагену внаслідок значного відкладання AGE (advanced glycation end)-продуктів [6-8, 11]. Зважаючи на тісний анатомічний контакт, структурні зміни решітчастої пластини можуть призвести до безпосереднього ураження зорового нерва та вторинного його пошкодження внаслідок порушення кровопостачання та аксоплазматичного току $[3,5,9,10,12,14]$.

Відомо, що товщина решітчастої пластини впливає на іiі біомеханічні властивості: тонка - приводить до підвищення градієнта тиску між внутрішньоочним середовищем та ретробульбарним цереброспинальним простором через зменшення відстані між ними $[3,4]$, товста ригідна - збільшує вірогідність пошкодження аксонів $[2,11]$.

Однак клінічного дослідження решітчастої пластини in vivo у хворих на ЦД не проводилось, не вивчено значення іiі товщини у патогенезі ДОН.

Мета роботи - вивчити морфометричні зміни решітчастої пластини склери та зміни площі іï склерального каналу у хворих на цукровий діабет залежно від типу та стадії ДОН та встановити клініко-патогенетичне значення морфометричних змін решітчастої пластини склери у розвитку ДОН.

Матеріали та методи. Аналіз особливостей ураження зорового нерва здійснювався на основі даних обстеження 575 хворих (1150 очей) на ЦД 2-го типу. Було відібрано групу хворих на ЦД 2-го типу з відсутньою глаукомою в анамнезі, у яких показники тонометричного тиску не перевищували 21 мм рт. ст. за Гольдманом. У дослідження включали очі з еметропією або з гіперметропією чи міопією слабкого ступеня; без катаракти або з початковою віковою катарактою; без хірургічних втручань на органі зору в анамнезі, у тому числі лазерних. Вік хворих коливався від 44 до 69 років, в середньому складав $55,9 \pm 7,8$ року. Тривалість захворювання на ЦД до 5 років відзначалася у більшості хворих (71,8 \%, 413 осіб), від 5 до 10 років - у 16,2 \% хворих (93 особи), вище 10 років - у 12,0 \% хворих (69 осіб). Залежно від рівня глікозильованого гемоглобіну крові компенсація ЦД ( $\mathrm{HbA} 1 \mathrm{C} \leq 7$ \%) спостерігалася у 78,3 \% хворих (450 осіб), субкомпенсація (7 \% $\geq \mathrm{HbA1C} \leq 9 \%$ ) - у 13,2 \% хворих (76 осіб), декомпенсація (НbA1C $\geq 9$ \%) - у 8,5 \% хворих (49 осіб).

Крім стандартних (візометрія, тонометрія, дослідження очного дна), методи офтальмологічного дослідження включали оптичну когерентну томографію (ОКТ) сітківки та зорового нерва. Для спектральної 
OКТ використовували RTVue-100 (Optovue, США) 3 роздільною здатністю 5 мікрон. Використовували новий спосіб вимірювання товщини решітчастої пластини склери за допомогою SD ОКТ із застосуванням програми LC_Thickness_programm.m та main_low_ noise_filters_programm.m, що грунтується на алгоритмі адаптивної компенсації для усунення шуму високого рангу в глибоких шарах головки зорового нерва й покращання візуалізації задньої межі решітчастої пластини, а також на обробці В-скану набором iз 3-х цифрових фільтрів: низькочастотного фільтра Батерворта інверсного зображення, низькочастотного фільтра аналізу вейвлет Добеши оригінального та інверсного зображення. Площу склерального каналу решітчастої пластини вимірювали за допомогою SD OKT: 3 використанням програми LC_cut_position programm.m для вибору глибини вимірювання та LC_ diameter_calculation_programm.m для покращання обраного зображення основними цифровими фільтрами та визначення найбільш якісного - для вимірювання.

Результати та їх обговорення. У хворих на ЦД відзначили потовщання решітчастої пластини склери. Так, показник товщини решітчастої пластини у хворих на ЦД коливався від 284 мки до 1203 мкм, у середньому складав $589 \pm 179$ мкм, а 95 \%-й інтервал довіри становив 415-887 мкм. У контрольній групі здорових осіб відповідного віку показник товщини решітчастої пластини коливався від 173 мки до 354 мкм, у середньому складав $303 \pm 56$ мкм, а $95 \%$-й інтервал довіри становив 415-887 мкм. Таким чином, середній показник товщини решітчастої пластини склери у хворих на ЦД перевищував такий у контрольній групі у 1,9 разу $(\mathrm{p}<0,001)$, що показано на рис. 1.

Слід відзначити, що товщина решітчастої пластини склери у всіх хворих на ЦД на правому оці достовірно не відрізнялась від такої на лівому оці $(\mathrm{p}>0,05)$. Особливості ураження зорового нерва залежно від товщини решітчастої пластини склери у хворих на ЦД стали основою для виділення наступних груп хворих:

1-a груnа - із незначним потовщенням решітчастої пластини склери $(<700$ мкм) - склала $78,6 \%$ очей хворих на ЦД (904 ока),

2-a група - із середнім потовщенням решітчастої пластини склери (700-900 мкм) - склала 17,6 \% очей хворих на ЦД (202 ока),

3-я група - зі значним потовщенням решітчастої пластини склери ( $<900$ мкм) - склала 3,8 \% очей хворих на ЦД (44 ока).

До 1-ої групи увійшло 73 \% очей хворих на ЦД без ДОН (660 очей), 22,8 \% очей із субклінічною стадією аксіальної ДОН (206 очей) та 4,2 \% очей із початковою стадією (38 очей) (рис. 2). 2-гу груnу

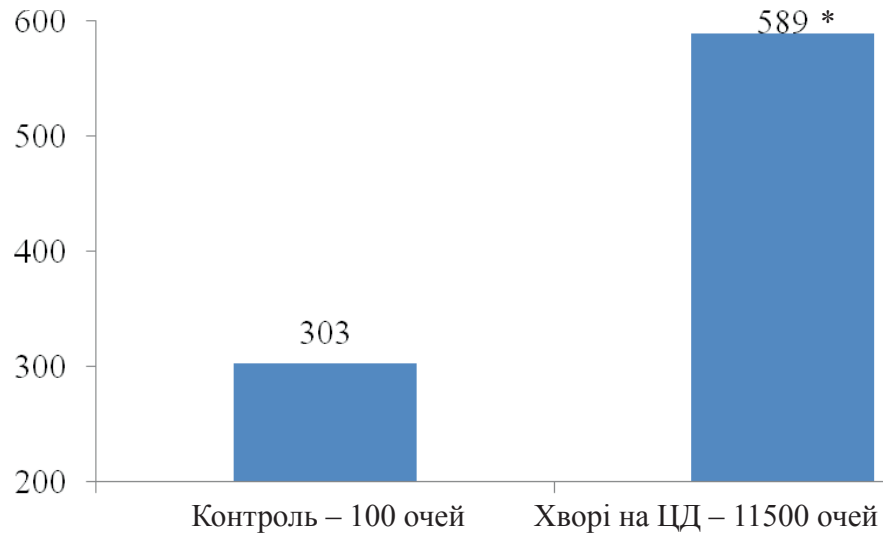

Puc. 1. Середній показник товщини решітчастої пластини у хворих на цукровий діабет

Примітка:

* - достовірна відмінність між середнім значенням показника у хворих на цукровий діабет та у контрольній групі

склали 43,5 \% очей з вираженою стадією аксіальної ДОН (88 очей), 28,2 \% очей - 3 початковою стадією (57 очей), 12,4 \% очей - із субклінічною стадією (25 очей), $11,9 \%$ очей - 3 передньою ішемічною ДОН (24 ока), 3,0 \% очей - 3 діабетичною папілопатією (6 очей) та $1 \%$ очей - 3 дистрофічною стадією аксіальної ДОН (2 ока). Переважну більшість (93,2 \%) 3-ої групи склали очі з дистрофічною стадією аксіальної ДОН (41 око), 6,8 \% - 3 вираженою стадією (3 ока).

У хворих на ЦД не виявили кореляції між товщиною решітчастої пластини склери та площею ії склерального каналу $(\mathrm{p}>0,05)$. Так, показник площі склерального каналу решітчастої пластини у хворих 1-ö̈ групи з незначним потовщенням решітчастої пластини склери коливався від $1,71 \boldsymbol{M м}^{2}$ до $5,53 \boldsymbol{M м}^{2}$, у середньому складав $2,77 \pm 0,82 \mathcal{M м}^{2}$, а $95 \%$-й інтервал

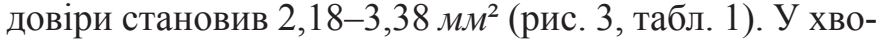
рих 2-ої групи із середнім потовщенням решітчастої пластини склери даний показник коливався від 1,15 $\mathcal{M м}^{2}$ до 5,58 $\boldsymbol{м м}^{2}$, у середньому складав $2,57 \pm 0,86 \boldsymbol{м м}^{2}$ з $95 \%$-м інтервалом довіри 2,01-3,17 $\boldsymbol{M м}^{2}$. У хворих 3-ої групи зі значним потовщенням решітчастої пластини склери показник площі склерального каналу

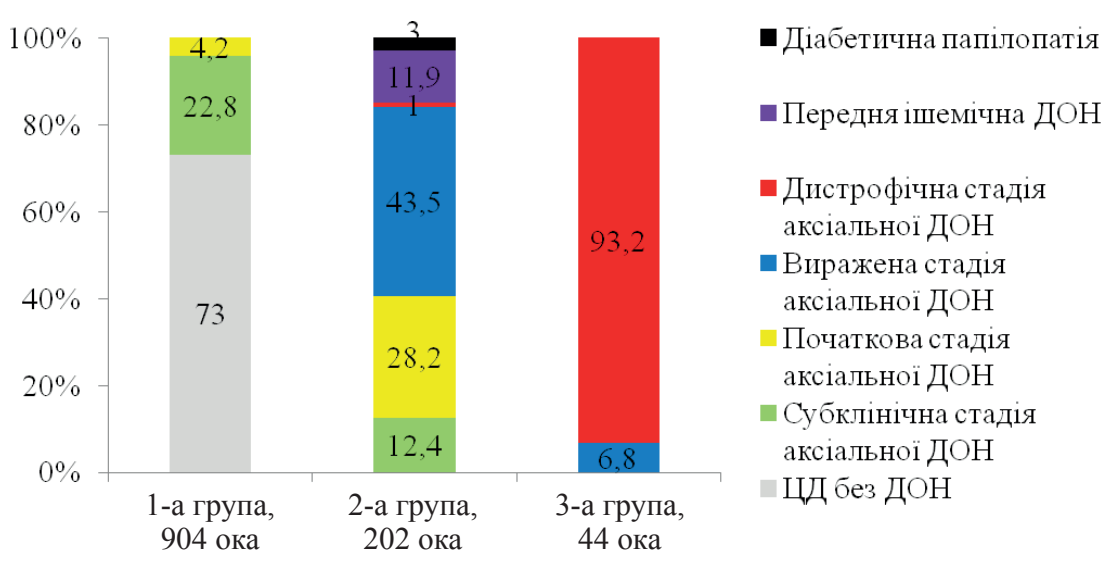

Рuc. 2. Розподіл хворих на цукровий діабет згідно товщини решітчастої пластини та типу і стадії діабетичної оптичної нейропатії 
Показники площі склерального каналу решітчастої пластини залежно від ії товщини у хворих на цукровий діабет

\begin{tabular}{|c|c|c|c|}
\hline \multirow{2}{*}{ Досліджувані групи } & \multicolumn{3}{|c|}{${\text { Показники, } \text { мм }^{2}}^{2}$} \\
\cline { 2 - 4 } & $\mathrm{M} \pm \mathrm{m}$ & Коливання & \% IД \\
\hline Контроль, $\mathrm{n}=100$ очей & $2,64 \pm 0,77$ & $1,74-5,43$ & $2,13-3,35$ \\
\hline 1-а група, $\mathrm{n}=904$ ока & $2,77 \pm 0,82$ & $1,71-5,53$ & $2,18-3,38$ \\
\hline 2-а група, $\mathrm{n}=202$ ока & $2,57 \pm 0,86$ & $1,15-5,58$ & $2,01-3,17$ \\
\hline 3-я група, $\mathrm{n}=44$ ока & $2,52 \pm 0,76$ & $1,62-5,34$ & $2,02-3,05$ \\
\hline
\end{tabular}

Показники товщини решітчастої пластини у хворих на діабетичну оптичну нейропатію залежно від типу та стадії захворювання

\begin{tabular}{|c|c|c|c|c|}
\hline \multirow{2}{*}{\multicolumn{2}{|c|}{ Досліджсувані групи }} & \multicolumn{3}{|c|}{ Показники, мкм } \\
\hline & & $\mathrm{M} \pm \mathrm{m}$ & Коливання & $95 \%$ ІД \\
\hline & нтроль, $\mathrm{n}=100$ & $303 \pm 56$ & $173-435$ & $265-354$ \\
\hline & ез ДОН, $n=660$ & $425 \pm 59 *$ & $284-578$ & $371-483$ \\
\hline & на папілопатія, $\mathrm{n}=6$ & $796 \pm 78 *$ & $688-882$ & $734-851$ \\
\hline & шемічна ДОН, $\mathrm{n}=24$ & $807 \pm 63^{*}$ & $698-895$ & $757-863$ \\
\hline \multirow{4}{*}{$\begin{array}{c}\text { Аксіальна } \\
\text { ДОН }\end{array}$} & субклінічна стадія, n=231 & $561 \pm 61 *$ & $467-678$ & $513-609$ \\
\hline & початкова стадія, $\mathrm{n}=95$ & $622 \pm 62 *$ & $512-707$ & $574-663$ \\
\hline & виражена стадія, n=91 & $793 \pm 75^{*}$ & $708-936$ & $749-838$ \\
\hline & дистрофічна стадія, $\mathrm{n}=43$ & $945 \pm 74 *$ & $807-1203$ & $897-989$ \\
\hline
\end{tabular}

\section{Примітки:}

* - достовірна відмінність між середнім значенням показника в досліджуваній та контрольній групах;

' - достовірна відмінність між середнім значенням показника у досліджуваній групі та групі хворих з дистрофічною аксіальною ДОН

решітчастої пластини склери коливався від 1,62 мм $^{2}$ до $5,34 \mathcal{M M}^{2}$, у середньому складав $2,52 \pm 0,76 \mathcal{M м}^{2}$, а $95 \%$-й інтервал довіри становив 2,02-3,05 мм² $^{2}$ Таким чином, середній показник площі склерального каналу решітчастої пластини склери у хворих на ЦД 3 незначним, середнім та значним потовщенням решітчастої пластини склери достовірно не відрізнявся від такого у контрольній групі $\left(2,64 \pm 0,77 \mathcal{M м}^{2}\right)(\mathrm{p}>0,05)$.

Аналізуючи показник товщини решітчастої пластини у хворих із ДОН виявили залежність від типу та стадії захворювання. Так, показник товщини решітчастої пластини у хворих на ЦД без ДОН коливався від 284 мкм до 578 мкм, у середньому складав $425 \pm 59$

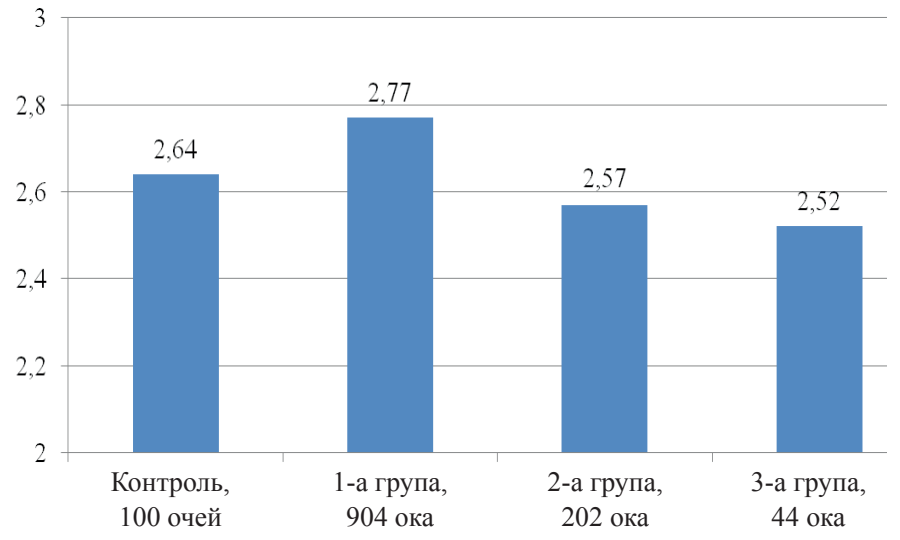

Puc. 3. Середній показник площі склерального каналу решітчастої пластини склери залежно від iіï товщини у хворих на цукровий діабет мкм, а 95 \%-й інтервал довіри становив 371-483 мкм (рис. 4, табл. 2). При діабетичній папілопатії даний показник коливався від 688 мкм до 882 мкм, у середньому складав $796 \pm 78$ мкм 395 \%-им інтервалом довіри 734-851 мкм. У хворих з передньою ішемічною

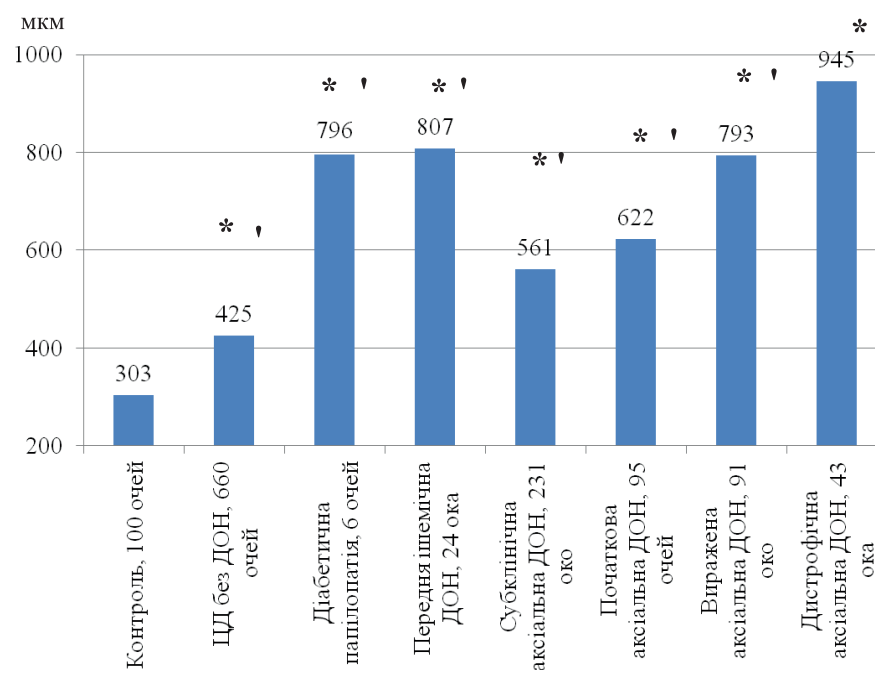

Puc. 4. Середній показник товщини решітчастої пластини у хворих на діабетичну оптичну нейропатію залежно від типу та стадії захворювання

Примітки:

* - достовірна відмінність між середнім значенням показника в досліджуваній та контрольній групах;

' - достовірна відмінність між середнім значенням показника у групі дослідження та у групі хворих з дистрофічною аксіальною ДОН 
ДОН показник товщини решітчастої пластини коливався від 698 мкм до 895 мкм, у середньому складав $807 \pm 63$ мкм, а $95 \%$-й інтервал довіри становив 757-863 мкм. При субклінічній стадії аксіальної ДОН даний показник коливався від 467 мкм до 678 мкм, у середньому складав $561 \pm 61$ мкм $395 \%$-им інтервалом довіри 513-609 мкм. У хворих з початковою стадією аксіальної ДОН показник товщини решітчастої пластини коливався від 512 мкм до 707 мкм, у середньому складав $622 \pm 62$ мкм, а $95 \%$-й інтервал довіри становив 574-663 мкм. При вираженій стадії аксіальної ДОН даний показник коливався від 708 мкм до 936 мкм, у середньому складав 793 \pm 75 мкм 3 $95 \%$-им інтервалом довіри 749-838 мкм. У хворих 3 дистрофічною стадією аксіальної ДОН показник товщини решітчастої пластини коливався від 807 мки до 1203 мк $и$, у середньому складав $945 \pm 74$ мк $м$, а $95 \%$-й інтервал довіри становив 897-989 мкм.

Таким чином, середній показник товщини решітчастої пластини у хворих на ЦД без ДОН перевищував відповідний у контрольній групі $(303 \pm 56$ мкм) $(\mathrm{p}<0,001)$ у 1,4 разу, при субклінічній стадії аксіальної ДОН - у 1,9 разу, початковій стадії- у 2,1 разу, вираженій стадії аксіальної ДОН та діабетичній папілопатії - у 2,6 разу, передній ішемічній ДОН - у 2,7 разу, дистрофічній стадії - у 3,1 разу.

Найвищий середній показник товщини решітчастої пластини відзначили у хворих з дистрофічною стадією аксіальної ДОН. У хворих на ЦД без ДОН даний показник був менший відповідного при дистрофічній стадії аксіальної ДОН ( $<00,001)$ у 2,2 разу, при субклінічній стадії аксіальної ДОН - у 1,7 разу, при початковій стадії - у 1,5 разу, при вираженій стадії аксіальної ДОН, при діабетичній папілопатії та передній ішемічній ДОН - у 1,2 разу.

Таким чином, у результаті проведених досліджень виявлено кореляцію між типом та стадією ДОН та станом решітчастої пластини склери у хворих на ЦД. Так, середній показник товщини решітчастої пластини у хворих на ЦД без ДОН перевищував відповідний у контрольній групі $(303 \pm 56$ мкм) $(\mathrm{p}<0,001)$ у 1,4 разу, при субклінічній стадії аксіальної ДОН - у 1,9 разу, при початковій стадії - у 2,1 разу, при вираженій стадії аксіальної ДОН та діабетичній папілопатії - у 2,6 разу, при передній ішемічній ДОН - у 2,7 разу, при дистрофічній стадії - у 3,1 разу.

\section{Висновки}

У результаті проведених досліджень у хворих на цукровий діабет було виявлено потовщення решітчастої пластини склери у порівнянні 3 показниками здорових осіб відповідного віку в середньому у 1,9 разу, причому у більшості $(78,6 \%)$ очей хворих на ЦД відзначалося незначне потовщення решітчастої пластини склери ( $<700$ мкм), у 17,6 \% очей - середнє потовщення (700-900 мкм), у 3,8 \% очей - значне потовщання $(<900$ мкм).

Доповнено наукові дані про механізми розвитку ДОН та показано, що одним із них $є$ потовщення решітчастої пластини склери: у хворих на ЦД без ДОН даний показник перевищує відповідний у здорових осіб такого ж віку в 1,4 разу, при субклінічній стадії аксіальної ДОН - у 1,9 разу, при початковій стадії - у 2,1 разу, при вираженій стадії аксіальної ДОН та діабетичній папілопатії - у 2,6 разу, при передній ішемічній ДОН - у 2,7 разу, при дистрофічній стадії - у 3,1 pazy.

\section{Література}

1. Скрипник Р. Л. Пошкодження зорового нерва при цукровому діабеті (патогенез, клініка, діагностика, лікування): автореф. дис. на здобуття наук. ступеня док. мед. наук : спец. 14.01.18 “Очні хвороби” / Р. Л. Скрипник. - Одеса, 2005. - 34 с.

2. Albon $J$. Changes in the collagenous matrix of the ageing human lamina cribrosa / J. Albon, W. S. Karwatowski, N. Avery [et al.] // Br J Ophthalmol. 1995. - Vol. 79. - P. 368-375.

3. Burgoyne C. F. A biomechanical paradigm for axonal insult within the optic nerve head in aging and glaucoma / C. F. Burgoyne // Exp Eye Res. - 2011. - Vol. 93 (2). - P. 120-132.

4. Jonas J. B. Anatomic relationship between lamina cribrosa, intraocular space, and cerebrospinal fluid space / J. B. Jonas, E. Berenshtein, L. Holbach // Invest Ophthalmol Vis Sci. - 2003. - Vol. 44. P. 5189-5195.

5. Kim J. H. Comparison of the Thickness of the Lamina Cribrosa and Vascular Factors in Early Normal-tension Glaucoma with Low and High Intraocular Pressures / J. H. Kim, T. Y. Lee, J. W. Lee [et al.] // Korean J Ophthalmol. - 2014. - Vol. 28 (6). - P. 473-478.

6. Lapolla A. Advanced glycation end products/peptides: an in vivo investigation / A. Lapolla, D. Fedele, R. Reitano [et al.] // Ann NY Acad Sci. - 2005. - Vol. 1043. - P. 267-275.

7. Park S. C. Horizontal central ridge of the lamina cribrosa and regional differences in laminar insertion in healthy subjects / S. C. Park, S. Kiumehr, C. C. Teng [et al.] // Invest Ophthalmol Vis Sci. - 2012. Vol. 53. - P. 1610-1616.

8. Reddy G. K. AGE-related cross-linking of collagen is associated with aortic wall matrix stiffness in the pathogenesis of drug-induced diabetes in rats / G. K. Reddy // Microvasc Res. - 2004 . -Vol. 68. P. 132-142.

9. Sigal I. A. Predicted extension, compression and shearing of optic nerve head tissues / I. A. Sigal, J. G. Flanagan, I. Tertinegg, C. R. Ethier // Exp Eye Res. 2007. - Vol. 85. - P. 312-322. 
10. Sigal I. A. Modeling individual-specific human optic nerve head biomechanics. Part II: influence of material properties / I. A. Sigal, J. G. Flanagan, I. Tertinegg, C. R. Ethier // Biomech Model Mechanobiol. - 2009. - Vol. 8 (2). - P. 99-109.

11. Spoerl E. The influence of various substances on the biomechanical behavior of lamina cribrosa and peripapillary sclera / E. Spoerl, A. G. Boehm, L. E. Pillunat // Invest Ophthalmol Vis Sci. - 2005. - Vol. 46 (4). - P. 1286-1290.

12. Tatham A. J. Defects of the lamina cribrosa in eyes with localized retinal nerve fiber layer loss / A. J. Tatham, A. Miki, R. N. Weinreb [et al.] // Ophthalmology. - 2014. - Vol. 121(1). - P. 110-118.
13. Terai N. Diabetes mellitus affects biomechanical properties of the optic nerve head in the rat / N. Terai, E. Spoerl, M. Haustein [et al.] // Ophthalmic Res. 2012. - Vol. 47 (4). - P. 189-194.

14. Winkler $M$. High resolution three dimensional reconstruction of the collagenous matrix of the human optic nerve head / M. Winkler, B. Jester, C. Nien-Shy [et al.] // Brain Res Bull. - 2010. - Vol. 81. - № 2-3. - P. 339.

15. Zhao J. P. Optic nerve lesions in diabetic rats: blood flow to the optic nerve, permeability of micro blood vessels and histopathology / J. P. Zhao, Z. Z. Ma, C. Song [et al.] // International Journal of Ophthalmology. - 2010. - Vol. 3(4). - P. 291-294.

\title{
ОСОБЕННОСТИ ТОЛЩИНЫ РЕШЕТЧАТОЙ ПЛАСТИНЫ СКЛЕРЫ У БОЛЬНЫХ С ДИАБЕТИЧЕСКОЙ ОПТИЧЕСКОЙ НЕЙРОПАТИЕЙ
}

\author{
П. А. Бездетко, М. А. Карлийчук
}

В работе описаны изменения толщины решетчатой пластины склеры у больных сахарным диабетом в сравнении с показателями здоровых лиц, а также изменения толщины решетчатой пластины склеры у больных с разными стадиями диабетической оптической нейропатии. Кроме того, приведены изменения площади склерального канала решетчатой пластины в зависимости от ее толщины у больных сахарным диабетом.

Ключевые слова: диабетическая оптическая нейропатия, решетчатая пластина склеры, сахарный диабет, склеральный канал.

\section{PECULIARITIES OF LAMINA CRIBROSA THICKNESS IN PATIENTS WITH DIABETIC OPTIC NEUROPATHY}

\author{
P. A. Bezditko ${ }^{1}$, M. A. Karliychuk ${ }^{2}$ \\ ${ }^{1}$ Kharkiv National Medical University of the Ministry of Public Health of Ukraine \\ Kharkiv, Ukraine \\ ${ }^{2}$ Bukovinian State Medical University of the Ministry of Public Health of Ukraine \\ Chernivtsi, Ukraine
}

Lamina cribrosa morphology is ever changing in health and disease, and its changes might cause primary optic nerve damage and secondary damage due to the decrease of blood supply and axoplasmic transport. There is no information in literature about the peculiarities of lamina cribrosa thickness in patients with diabetic optic neuropathy $(\mathrm{DON})$ in vivo.

The objective was to study the morphometric changes of the lamina cribrosa and changes of its scleral canal in patients with diabetes mellitus (DM) depending on the type and stage of the diabetic optic neuropathy, and to establish the clinicopathogenetic role of lamina cribrosa morphometric changes in the development of DON.

Materials and methods. 575 patients (1150 eyes) with type II DM were examined. In addition to standard ophthalmologic methods optical coherent tomography (OCT) of the retina and optic nerve was performed. Lamina cribrosa thickness was measured with the help of SD OCT using LC_Thickness_programm.m and main_low_ noise_filters_programm.m, based on the adaptive compensation algorithm for eliminating a high-level noise in the deep layers of the optic nerve and improving the visualization of the posterior border of the lamina cribrosa, as well as for processing B-scan with a set of 3 digital filters: Butterworth Low-pass Filter inverion image, Wavelet Low-pass Filter Analysis Daubechies original and inversion image. The area of lamina cribrosa scleral canal was measured with the help of SD OCT using the LC_cut_position_programm.m for choosing the depth of measurement and LC_diameter_calculation_programm.m for improvement of the selected image by the main digital filters.

Results. Analyzing the results of examination, the correlation between the type and stage of DON and scleral lamina cribrosa thickness in patients with DM was revealed. An average index of lamina cribrosa thickness in patients with DM without diabetic optic neuropathy was 1.4 times higher than that of the control group; in subclinical stage of axial DON - 1.9 times higher, in initial stage - 2.1 times higher, in severe stage of axial DON and diabetic papillopathy - 
2.6 times higher, in anterior ischemic DON - 2.7 times higher, in dystrophic stage -3.1 times higher than that of the control group $(303 \pm 56 \mu \mathrm{m})(\mathrm{p}<0,001)$.

Conclusions. As a result of the study a thickening of scleral lamina cribrosa in average 1.9 times greater as compared to healthy persons of an appropriate age was found. In $78.9 \%$ of eyes of the patients with DM a mild thickening of scleral lamina cribrosa $(<700 \mu \mathrm{m})$ was observed; in $16.6 \%$ of eyes a moderate thickening $(700-900 \mu \mathrm{m})$, and in $3.8 \%$ of eyes - a significant thickening $(<900 \mu \mathrm{m})$ was observed. The scientific data about the mechanisms of diabetic optic neuropathy were amplified. A thickening of scleral lamina cribrosa was found to play an essential role in the pathogenesis of diabetic optic neuropathy.

Key words: diabetic optic neuropathy, scleral lamina cribrosa, diabetes mellitus, scleral canal.

Стаття надійшла до редакції 09.03.2018 p.

І. В. Галінська

Вінницький національний медичний університет імені М. І. Пирогова

МОЗ України

- м. Вінниця, Україна

\title{
РОЗПОВСЮДЖЕНІСТЬ ТА ЕТІОЛОГІЯ ЧАСТКОВОÏ АТРОФІЇ ЗОРОВОГО НЕРВА
}

\begin{abstract}
Атрофія зорових нервів - важка поліетіологічна офтальмопатія, яка є одним із основних етіопатогенетичних чинників сліпоти, слабобачення та причин інвалідизації по зору.

Метою дослідження було проведення аналізу розповсюдженості та етіологічних факторів часткової атрофії зорового нерва (ЧАЗН). Був проведений ретроспективний аналіз 74 історій хвороб пацієнтів (137 очей) на ЧАЗН за період 2012-2016 pр. Встановлено, що вражається населення працездатного віку (середній вік $50,0 \pm 2,5$ року), і це підкреслює соціальну значимість даної проблеми. Переважно двобічна локалізація патологічного процесу (у 86 \% хворих) збільшує ризик інвалідизації внаслідок даної патології. У жінок ЧАЗН частіше має характер судинного генезу (52,9 \% випадків), а у чоловіків - запальної етіології (43,5 \% випадків).
\end{abstract}

Ключові слова: зоровий нерв, атрофія зорового нерва, розповсюдженість атрофії зорових нервів, етіологія.

Атрофія зорових нервів (АЗН) - важка поліетіологічна офтальмопатія, до розвитку якої призводять загальні захворювання (75,8 \%), вроджена патологія (18 \%) та травми (3-6,2\%). Захворювання є одним iз основних етіопатогенетичних чинників сліпоти, слабобачення (недобачання) та інвалідизації по зору [7-11].

За даними статистики в Україні за 7 років, частота АЗН як основної тяжкої нозологічної форми офтальмопатології у первинних інвалідів по зору склала в: 2011 році - 7,9\%, $2012-8,1 \%, 2013-7,9 \%, 2014$ $-8,9 \%, 2015-8,5 \%$. У 2016 році інтенсивний показник АЗН на 10 тис. дорослого населення склав 0,16. Серед первинних інвалідів 3 дитинства іiі частота склала 7,7 \% [1-6].
Серед етіологічних чинників АЗН переважають захворювання ЦНС: об'ємні процеси головного мозку (запалення мозку та його оболонок, пухлини, черепно-мозкові травми, порушення центрального кровообігу, абсцеси, гематоми, аневризми, туберкуломи, паразитарні кісти та кісти після геморагічного інсульту, спадкові ураження), нейроінфекції (менінгіти, енцефаліти, базальні арахноїдіти, розсіяний склероз), ішемічна хвороба серця, гіпертонічна хвороба, цукровий діабет, атеросклероз. За даними окремих авторів, чинниками ризику АЗН стали ішемічна хвороба серця $(23,43 \%)$, гіпертонічна хвороба $(20,56 \%)$, атеросклероз (18,6\%) [12-14].

За даними літератури, все більшого значення набувають токсичні та токсико-алергічні ураження зо- 